\title{
Attachment and replication of Pseudomonas aeruginosa bacteriophages under conditions simulating aquatic environments
}

\author{
Tyler A. KoKJohn, ${ }^{1,2 *}$ Gary S. SAYLeR ${ }^{3}$ and Robert V. MilleR ${ }^{2} \dagger$ \\ ${ }^{1}$ Environmental Research Division, Argonne National Laboratory, Argonne, IL 60439, USA \\ ${ }^{2}$ Department of Molecular and Cellular Biochemistry, Stritch School of Medicine, Loyola University of Chicago, \\ Maywood, IL 60153 USA \\ ${ }^{3}$ Department of Microbiology and The Graduate Program in Ecology, Center for Environmental Biotechnology, \\ University of Tennessee, Knoxville, TN 37932-2567, USA
}

\begin{abstract}
Bacterial viruses are important in regulating bacterial population densities in natural aquatic environments, but the dynamics of bacteriophage-bacterial interactions in nature are poorly understood. In this study, the attachment and replication of three Pseudomonas aeruginosa bacteriophages (one temperate and two virulent) were investigated under conditions similar to those found in nature. Attachment and replication of bacteriophages were not impaired at host-cell densities equal to or lower $\left(<10^{5} \mathrm{c.f}\right.$.u. $\left.\mathrm{ml}^{-1}\right)$ than those frequently found in aquatic environments when the host cells were physiologically competent to allow phage growth. Attachment (45-93\%) to either actively growing or starved cells was not impaired in river water, indicating that attachment is efficient in natural freshwater habitats. However, the replication of bacteriophages was significantly altered in starved cells in river water: the latency period was extended (broth, 70-110 $\mathrm{min}$; river water, 110-240 $\mathrm{min}$ ), and the burst size was reduced (broth, 27-65; river water 5-7). The findings of this study indicate that phages are likely to affect microbial ecology significantly in freshwater ecosystems.
\end{abstract}

\section{Introduction}

The recent observations of the high incidence of bacterial viruses in aquatic environments (Bergh et al., 1989; Børsheim et al., 1990; Ogunseitan et al., 1990; Proctor \& Fuhrman, 1990) have brought into question many previous conclusions about the ecology of aquatic microbial populations. The interactions of bacteriophages with their hosts may be a prime factor affecting the ecology, evolution and abundance of micro-organisms in many natural habitats. However, the dynamics of bacteriophage-host interactions in natural aquatic ecosystems are poorly understood at present.

The abundance of apparently active phages in many aquatic environments suggests that phages may share the role of bacterial predators with heterotrophic nanoplankton in controlling bacterial population densities in these ecosystems (Bratbak et al., 1990). Viral-host interactions have the potential of significantly affecting bacterial

* Correspondence should be sent to the Argonne National Laboratory.

$\dagger$ Present address: Department of Microbiology, Oklahoma State University, Stillwater, Oklahoma, 74078-0266 USA.

Abbreviation: IC, infectious centre. abundance in natural ecosystems (Torrella \& Morita, 1979; Bergh et al., 1989), but the impact of bacterial viruses on natural microbial communities depends on the productive interaction of hosts and viruses. The ability of phages to control or eliminate populations or subpopulations from natural microbial communities depends on the efficiency with which these interactions occur. If bacteriophages are effective in regulating bacterial abundance, resistance to viral infection may give a selective advantage to certain subpopulations in specific habitats. The importance of viral-mediated gene exchange in the reassortment of genetic determinants to create advantageous genotypes depends on the effectiveness of viral expression and replication.

To estimate the effects of bacteriophages on the development, ecology and evolution of natural microbial communities, both the probability and efficiency of viral infection and production must be fully understood. The dynamics of phage replication in aquatic ecosystems are not well defined, and many questions concerning hostphage interactions in nature are yet to be answered. To determine the ability of bacteriophages to replicate under environmental conditions, we performed a series of experiments that duplicate certain aspects of the natural aquatic environment. Pseudomonas aeruginosa, a 
common member of aquatic and terrestrial microbial communities, and its bacteriophages were used as a model system for these studies.

\section{Methods}

Bacteria and bacteriophages. P. aeruginosa strains PAO303 (argB21; Kokjohn \& Miller, 1988) and PAC5 (his-5; McBeth, 1989) were used in this study. Three bacteriophages were compared: F116L (Krishnapillai, 1971), E79 (Holloway et al., 1960) and UT1 (Ogunseitan et al., 1990). F116L and E79 have been maintained in laboratory stocks for over 20 years while UT1 is a recent isolate from a freshwater lake.

Media. Luria broth (LB) consisted of $1 \%(\mathrm{w} / \mathrm{v})$ tryptone, $1 \% \mathrm{NaCl}$ and $0.5 \%$ yeast extract. Luria agar was LB containing $1.3 \%$ agar. Lambda top agar was $1 \%$ tryptone, $0.5 \% \mathrm{NaCl}$ and $0.65 \%$ agar.

Phage one-step growth experiments. (i) Actively growing cells. Cells to be infected were grown in $\mathrm{LB}$ at $30^{\circ} \mathrm{C}$. The cells were mixed with phage particles at a low multiplicity of infection (m.o.i. $<1$ ) in LB. Infection was allowed to proceed at room temperature $\left(25^{\circ} \mathrm{C}\right)$ for approximately $20 \mathrm{~min}$. The moment of mixture of phage and cells was taken as time zero for the experiments. At the end of the room temperature adsorption period, infected cells were diluted in LB and incubated at $30^{\circ} \mathrm{C}$. Samples were withdrawn at selected times. The total number of phage-forming units (p.f.u.) was determined by calculating the number of infectious centres (ICs). To accomplish this, samples were mixed with $0.1 \mathrm{ml}$ of phage-sensitive cells ( $P$. aeruginosa PAO303). The number of unabsorbed phages was determined by lysing duplicate samples taken at the end of the adsorption period with 0.1 vol chloroform and plating on PAO303. Chloroform did not affect the plating efficiency of the phages used under these experimental conditions (data not shown).

(ii) Starved cells. Starved cells were prepared from LB cultures of PAO303 in the early exponential phase. The culture was then diluted 1:10 in autoclaved river water obtained from the Des Plaines River in Maywood, Illinois, USA, and incubation was continued at $30^{\circ} \mathrm{C}$ overnight (at least $20 \mathrm{~h}$ ). Infection was accomplished as detailed above for growing cells except that both phage and infected cells were diluted in autoclaved river water. The numbers of ICs and unabsorbed phage were determined as described for growing cells. The indicator strain was PAO303 grown on LB.

Phage attachment in river water. Cells were grown in $\mathrm{LB}$ at $30^{\circ} \mathrm{C}$ to the early exponential phase, harvested by centrifugation and suspended in an equal volume of autoclaved river water. Phages were diluted in autoclaved river water, and infection was allowed to occur at room temperature for approximately $20 \mathrm{~min}$. At the conclusion of the adsorption period, ICs and unabsorbed phage particles were quantified as described for the one-step growth experiments. The indicator strain was PAO303 grown in LB.

Phage attachment to starved cells. Starved cells were obtained as detailed for the one-step growth experiments. Unabsorbed phage particles and ICs were determined as for all other experiments, with $\mathrm{PAO} 303$ as the indicator.

\section{Results and Discussion}

\section{Effects of host-cell density on phage replication}

The replication of phages under the conditions prevalent in natural ecosystems has not been extensively exam- ined. Previous studies of bacteriophages and bacterial host cells have been interpreted as indicative of a minimum required host-cell density of $10^{4} \mathrm{c}$.f.u. $\mathrm{ml}^{-1}$ for effective phage replication (Wiggins \& Alexander, 1985). However, that study did not separate the possible influence of host-cell density on the infective process from its effect on the replicative process. To determine the ability of phages to replicate at low host-cell densities $\left(<10^{4}\right.$ c.f.u. $\left.\mathrm{ml}^{-1}\right)$, we performed a series of one-step growth experiments with a modification of the methods of Ellis \& Delbrück (1939). Using this protocol allowed the processes of replication and infection to be examined separately.

For these experiments we used three $P$. aeruginosa bacteriophages. In hosts growing under laboratory conditions, phage F116L (Krishnapillai, 1971) displays the temperate phenotype, while phages E79 (Holloway $e t$ al., 1960) and UT1 (Ogunseitan et al., 1990) are virulent. Under appropriate conditions, each of these phages will mediate generalized transduction (Krishnapillai, 1971; Morgan, 1979; S. Ripp \& R.V. Miller, unpublished).

Phage growth was assayed at several host-cell densities $\left(10^{1}-10^{5}\right)$. The development of progeny phages was determined by the IC assay (Ellis \& Delbrück, 1939). Our experiments indicated that cells infected by the use of the one-step protocol yield significant bursts of progeny phages after a latent period. As evidenced by the kinetics of phage release and burst size, host-cell density did not significantly affect phage development under these conditions (Fig. 1, Table 1).

These experiments clearly demonstrate that both virulent and temperate phages of $P$. aeruginosa can replicate at low host-cell densities that are similar to those observed at several aquatic field sites (Saye et al., 1987, 1990; O'Morchoe et al., 1988; Ogunseitan et al., 1990). No limitation or threshold value of host-cell density was observed for phage replication in our experiments. Other studies of bacteriophages have demonstrated that a single infected cell can yield a burst of phage particles (Hayes, 1964).

\section{Examination of the ability of bacteriophages to infect host cells under environmental conditions}

Although, for the phages examined, host-cell density clearly does not limit phage replication under optimal growth conditions, phage production might still be subject to certain limitations in the natural environment. An understanding of the ability of phages to attach to and infect competent host cells under the physicochemical conditions of aquatic ecosystems is critical. We examined several factors that could potentially affect the ability of bacteriophages to infect host cells. 


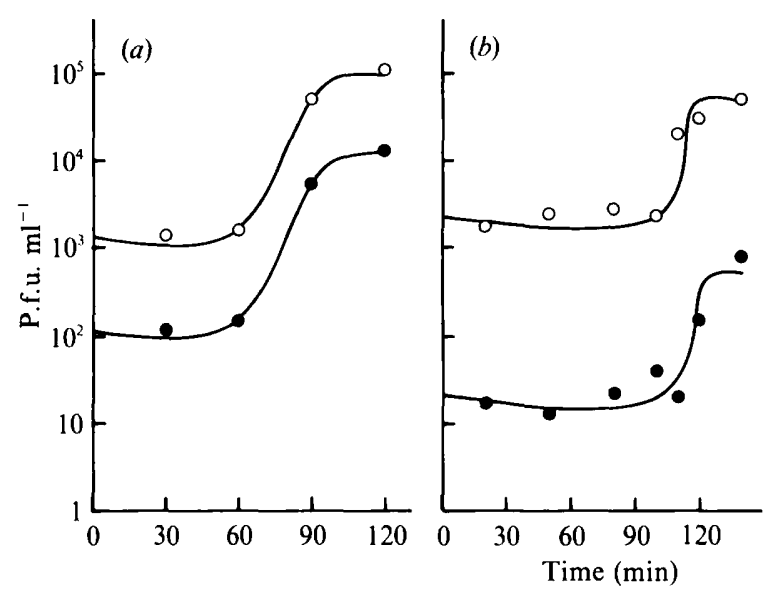

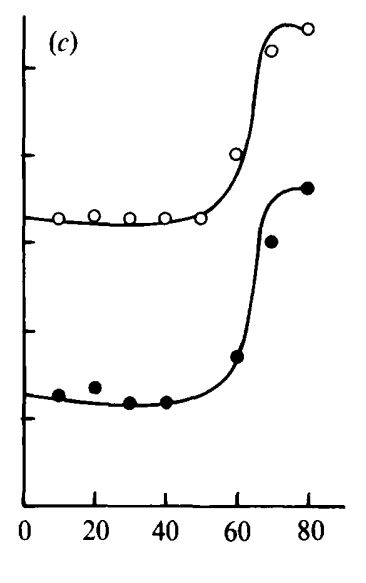

Fig. 1. One-step growth curves of phages infected into actively growing cells at low host-cell densities. PAO303 growing in LB was mixed with various phages at an m.o.i. $\approx 1$ and a one-step growth experiment was carried out as described in Methods. (a) Phage UT1: $\mathrm{O}, 1 \times 10^{3}$ c.f.u. $\mathrm{ml}^{-1}$ (burst size $=67$ ); $\bullet, 1 \times 10^{2}$ c.f.u. $\mathrm{ml}^{-1}$ (burst size $=87$ ). (b) Phage F116L: O, $2 \times 10^{3}$ c.f.u. $\mathrm{ml}^{-1}$ (burst size $=27$ ); $\bullet, 2 \times 10^{1}$ c.f.u. $\mathrm{ml}^{-1}$ (burst size =36). (c) Phage E79: $0,2 \times 10^{3}$ c.f.u. $\mathrm{ml}^{-1}$ (burst size $=100$ ); $\bullet, 2 \times 10^{1}$ c.f.u. $\mathrm{ml}^{-1}$ (burst size $=110$ ).
Table 1. Latent period and burst size of viruses replicating in PAO303 hosts at various host-cell densities and in various media

Experiments were done as described in Figs 1 and 2. Latency period is defined as the time from infection to the onset of cell lysis. The burst size is the average number of progeny virions produced from the infected cell.

\begin{tabular}{|c|c|c|c|c|}
\hline $\begin{array}{l}\text { Growth } \\
\text { medium }\end{array}$ & Phage & $\begin{array}{c}\text { Host-cell } \\
\text { density } \\
\left.\text { (c.f.u. } \mathrm{ml}^{-1}\right)^{*}\end{array}$ & $\begin{array}{l}\text { Latent period } \\
\quad(\min ) \dagger\end{array}$ & $\begin{array}{l}\text { Burst } \\
\text { sizeł }\end{array}$ \\
\hline LB & $\begin{array}{l}\text { F116L } \\
\text { E79 } \\
\text { UT1 }\end{array}$ & $\begin{array}{l}10^{1}-10^{5} \\
10^{1}-10^{5} \\
10^{1}-10^{4}\end{array}$ & $\begin{array}{c}100-110 \\
55-65 \\
70-80\end{array}$ & $\begin{array}{l}27 \pm 4 \\
91 \pm 14 \\
65 \pm 13\end{array}$ \\
\hline River water & $\begin{array}{l}\text { F116L } \\
\text { UT1 }\end{array}$ & $\begin{array}{l}10^{4}-10^{5} \\
10^{3}-10^{4}\end{array}$ & $\begin{array}{l}\geq 240 \\
\geq 110\end{array}$ & $\begin{array}{l}4 \pm 2 \\
6 \pm 3\end{array}$ \\
\hline
\end{tabular}

* The range of host-cell densities tested is shown.

$\dagger$ The range of latent periods calculated for all experiments is given. ¥ The mean and standard error of three or four determinations are given.

(i) Low-density infection experiments. The probability of productive phage-host interaction is an important parameter affecting phage ecology. The ability of phages to infect host cells productively was assayed at high $\left(\approx 10^{7}-10^{8} \mathrm{ml}^{-1}\right)$ and low $\left(\approx 10^{2} \mathrm{ml}^{-1}\right)$ host and phage densities (Table $2 a$ ). The ability of phages to infect susceptible cells was maintained at total particle densities characteristic of natural aquatic ecosystems.

Even though the total particle density in some of these experiments was low, the probability of interaction of bacterium and phage may not be related in a simple fashion to this density. Under the conditions used in our experiments, $P$. aeruginosa PAO cells are motile (T. A. Kokjohn \& R. V. Miller, unpublished). The mobility of the host cell may tend to counteract any effect of low particle density on infection probability. Because the motile cells effectively occupy a much larger volume, phage-host interaction remains likely despite the low total particle density.

The structure of microbial communities in nature is also of significance in determining probabilities of phage-bacterium interaction. Because bacterial communities often are not merely composed of dispersed cells but are assemblages of cells in close proximity (Harvey \& Young, 1980; Iriberri et al., 1987), the probability of interaction in these structured communities may be far greater than overall biological particle densities would predict. The ability of cells to move chemotactically to areas favourable for growth may result in higher cell densities and greater probabilities of interaction.

(ii) Attachment of phages to competent cells under physicochemical conditions found in river water. In many phage-bacterial systems, the ability of phages to attach to their hosts has been demonstrated to be strongly influenced by the ionic composition of the adsorption medium (Hayes, 1964). Therefore, we determined the ability of bacteriophages F116L and UT1 to adsorb to PAO303 cells suspended in river water. For these experiments PAO303 grew under conditions that definitely allowed for phage infection and replication. These experiments allowed effects on phage attachment to be examined separately from effects on cellular physiology. Under these conditions, PAO303 cells can clearly adsorb phage particles (Table $2 a$ ).

\section{Attachment of phages to starved cells}

During the process of starvation, bacterial cells undergo dramatic physical and physiological alterations (Dawes, 1985; Morita, 1985) that may induce corresponding changes in the ability of phages to adsorb to potential 
Table 2. Attachment of bacteriophages to hosts under various conditions simulating aquatic environments

Total and unabsorbed phages were calculated as described in Methods. Host cells were mixed with phages in LB at an m.o.i. $\approx 1$. (a) Frequency of phage attachment at high and low cell and phage densities. PAO303 was grown in LB to the early exponential phase. (b) Attachment to competent cells under physicochemical conditions found in aquatic ecosystems. Experiments were done as described in (a), except that PAO303 and phages were diluted in autoclaved river water. Infection was allowed to proceed as described in Methods. (c) Phage attachment to starved cells. Experiments were done as described in (a), except that PAO303 was starved in river water for at least $20 \mathrm{~h}$ before infection (carried out as described in Methods). (d) Attachment of phages to long-term starved host cells. Experiments were done as described in $(c)$, except that PAC5 was starved for $>40 \mathrm{~d}$ in river water.

\begin{tabular}{|c|c|c|c|c|}
\hline Phage & $\begin{array}{l}\text { Approximate } \\
\text { cell density } \\
\text { (c.f.u. } \mathrm{ml}^{-1} \text { ) }\end{array}$ & $\begin{array}{l}\text { Total phage } \\
\left(\mathrm{IC} \mathrm{ml}^{-1}\right)^{*}\end{array}$ & $\begin{array}{c}\text { Unabsorbed } \\
\text { phage } \\
\left.\text { (p.f.u. } \mathrm{ml}^{-1}\right)^{*}\end{array}$ & $\begin{array}{l}\text { Percentage } \\
\text { attachment* }\end{array}$ \\
\hline \multicolumn{5}{|c|}{ (a) Frequency of phage attachment at high and low cell and phage densities } \\
\hline $\begin{array}{l}\text { UT1 } \\
\text { F116L }\end{array}$ & $\begin{array}{l}\approx 10^{7} \\
\approx 10^{2} \\
\approx 10^{7} \\
\approx 10^{2}\end{array}$ & $\begin{array}{l}3.4 \pm 2.1 \times 10^{7} \\
1.8 \pm 0.2 \times 10^{2} \\
1.7 \pm 0.1 \times 10^{7} \\
2.5 \pm 0.2 \times 10^{2}\end{array}$ & $\begin{array}{l}1.6 \pm 1.3 \times 10^{7} \\
3.6 \pm 0.1 \times 10^{1} \\
4.5 \pm 1.4 \times 10^{6} \\
2.4 \pm 0.3 \times 10^{1}\end{array}$ & $\begin{array}{l}66 \pm 11 \\
80 \pm 3 \\
74 \pm 8 \\
35 \pm 17\end{array}$ \\
\hline \multicolumn{5}{|c|}{ (b) Attachment to competent cells under physicochemical conditions found in aquatic ecosystems } \\
\hline $\begin{array}{l}\text { UT1 } \\
\text { F116L }\end{array}$ & $\begin{array}{l}\approx 10^{7} \\
\approx 10^{6}\end{array}$ & $\begin{array}{l}2.1 \pm 0.5 \times 10^{7} \\
3.9 \pm 2.3 \times 10^{6}\end{array}$ & $\begin{array}{l}1.1 \pm 0.5 \times 10^{7} \\
1.3 \pm 1.1 \times 10^{6}\end{array}$ & $\begin{array}{l}59 \pm 16 \\
59 \pm 9\end{array}$ \\
\hline \multicolumn{5}{|c|}{ (c) Phage attachment to $24 \mathrm{~h}$ starved cells } \\
\hline $\begin{array}{l}\text { UT1 } \\
\text { F116L }\end{array}$ & $\begin{array}{l}\approx 10^{7} \\
\approx 10^{7}\end{array}$ & $\begin{array}{l}1.8 \pm 0.3 \times 10^{7} \\
1.3 \pm 0.5 \times 10^{7}\end{array}$ & $\begin{array}{l}8.5 \pm 1.1 \times 10^{5} \\
4.1 \pm 1.3 \times 10^{6}\end{array}$ & $\begin{array}{l}94 \pm 2 \\
61 \pm 6\end{array}$ \\
\hline \multicolumn{5}{|c|}{ (d) Phage attachment to long-term $(>40$ d) starved cells } \\
\hline $\begin{array}{l}\text { UT1 } \\
\text { F116L }\end{array}$ & $\begin{array}{l}\approx 10^{7} \\
\approx 10^{6}\end{array}$ & $\begin{array}{l}1.7 \pm 0.1 \times 10^{7} \\
5.2 \pm 2.5 \times 10^{6}\end{array}$ & $\begin{array}{l}9.3 \pm 0.2 \times 10^{6} \\
1.8 \pm 1.2 \times 10^{6}\end{array}$ & $\begin{array}{l}44 \pm 11 \\
60 \pm 18\end{array}$ \\
\hline
\end{tabular}

* The mean and standard error of three or four repetitions of each experiment are shown.

host cells. An assessment of the ability of $P$. aeruginosa PAO303 to adsorb phages F116L and UT1 after a minimum of $20 \mathrm{~h}$ starvation in river water (Table $2 c$ ) showed that these cells can support attachment. Furthermore, $P$. aeruginosa PAC5 cells starved for long periods ( $>40 \mathrm{~d}$ ) were still capable of phage adsorption (Table $2 d$ ). Experiments with PAC5 cells in LB have shown absorption of both F116L and UT1 $(70 \%$ and $47 \%$ respectively). Therefore, long-term starvation does not appear to decrease the ability of PAC5 to adsorb phages. Cadieux et al. (1983) demonstrated that the density of E79 receptors on the $P$. aeruginosa cell envelope is altered by various environmental factors such as temperature. So, because of the added complexities this phenomenon imposes on the test system, E79 was not used in this set of experiments.

\section{Replication of phages in starved host cells}

Cells existing in natural aquatic ecosystems are subject to nutrient deprivation (Rozak \& Colwell, 1987), and their physiology is significantly altered (Dawes, 1985; Morita, 1985). Because the replication of phages often depends on the growth potential of the host (Hayes, 1964), the physiological competence of the host may limit phage reproduction. Our test of the ability of phages F116L and UT1 to replicate in starved host cells showed that starvation affected phage replication significantly (Fig. 2). Even though the ability of phages to attach to cells that have undergone extensive periods of starvation is not impaired, the ability of infected starved cells to produce a burst of progeny virions is clearly reduced. When progeny phages were produced, the length of the latent period was increased and variable, and the size of the burst was significantly reduced (Table 1).

\section{Potential for phage-host interaction under environmental conditions}

The experiments reported here suggest that, at least for certain phages of $P$. aeruginosa, there is no limiting hostcell density for phage replication. Phages are capable of adsorption under the conditions found in nature and, moreover, to cells subsisting in such conditions. These data indicate that the ability of phages to replicate in starved cells is reduced but not eliminated. Taken together, these experiments suggest that phages will significantly affect bacterial populations in nature. 


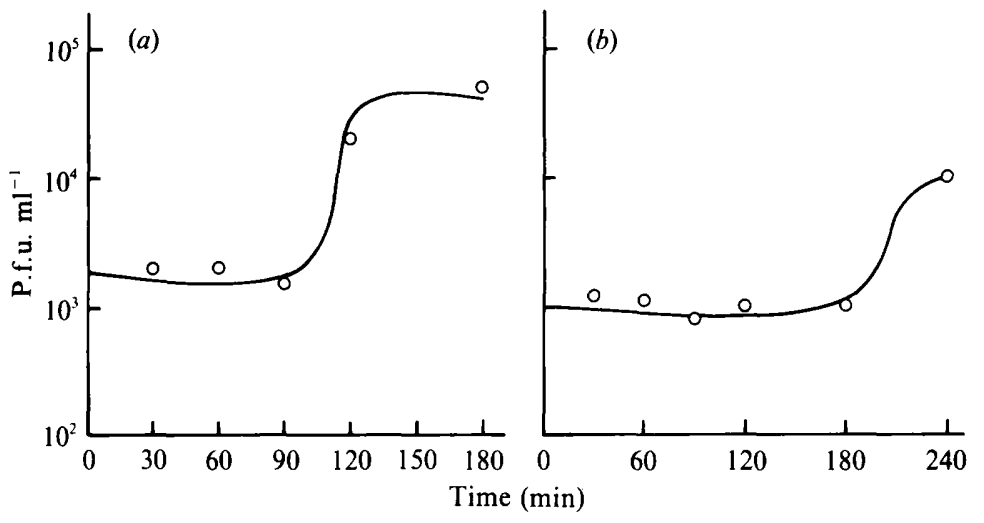

Fig. 2. One-step growth curves of phage infected into starved cells. PAO303 was grown in LB to the early exponential phase and then diluted $1: 10$ in autoclaved river water and incubated overnight (at least $20 \mathrm{~h}$ ). Cells and phage were mixed at an m.o.i. $\approx 1$ and a one-step growth experiment was carried out as described in Methods. (a) Phage UT1. (b) Phage F116L.
Our data suggest that when a population of physiologically competent host cells is present, phage replication can take place, rapidly leading to bursts of cell lysis and possibly gene exchange. The dynamics of phage replication during periods of nutrient limitation are not yet clear. Temperate phages such as F116L may simply rely on the continued presence of the phage genome (prophage) in the lysogenized host to maintain the virus during these periods. However, virulent phages such as UT1 have finite half-lives of 12-24 h (Ogunseitan et al., 1990), which are unlikely to be sufficient to ensure continued existence of the virus during periods of hostcell starvation.

Preliminary results from our laboratory (T. A. Kokjohn \& R. V. Miller, unpublished) indicate that the virulence of these viruses may be an artifact of the laboratory, where they are routinely exposed to physiologically competent hosts. For instance, UT1 exposed to starved cells appears to establish a pseudolysogenic relationship with its host (T. A. Kokjohn \& R. V. Miller, unpublished). In pseudolysogeny, first described in detail by Romig \& Brodetsky (1961) for a bacteriophage of Bacillus subtilis isolated from soil, viruses establish a close association with the host that resembles lysogeny in many respects. However, stable lysogens cannot be isolated under standard laboratory conditions when the host species is grown in rich medium, and the virulent phenotype (clear plaque) is nearly always observed.

Although lysogens of UT1 cannot be obtained in the laboratory, $45 \%$ of presumptive Pseudomonas isolates from the field site from which UT1 was obtained (Fort Loudoun Reservoir, Knoxville, Tennessee, USA) tested positive for colony hybridization when probed with UT1 DNA (Ogunseitan et al., 1990). Similar frequencies were observed in a lakewater microcosm containing UT1 and a susceptible $P$. aeruginosa host (Ogunseitan et al., 1990). Thus, bacteriophages have apparently developed strategies for surviving during periods of nutrient deprivation.
However, the ultimate fate of phages attached to a starved cell incapable of producing a burst of progeny virions is not known. Experiments addressing this question are now in progress.

Cyclic episodes of phage proliferation and inactivity in an ecosystem may produce an equilibrium of bacterial and phage abundances that can be misinterpreted as indicating a requirement for a minimum host density for phage replication. Ogunseitan et al. (1990) observed that the number of susceptible host bacteria was stabilized at $10^{4}$ c.f.u. $\mathrm{ml}^{-1}$ during a 45 -day incubation in a lakewater microcosm when UT1 was present. Børsheim et al. (1990) obtained similar results in a marine microcosm during a 21-day incubation.

The hypothesis that bacteriophages are insignificant bacterial predators is no longer tenable. The data obtained in this study clearly show that bacteriophages can productively interact with their hosts at concentrations and under conditions found in nature. These observations, coupled with data from the literature, lead to the conclusions that phages are important effectors of microbial ecology in natural aquatic ecosystems and that they exist in dynamic equilibrium with their hosts. Thus, the potential of bacterial viruses to control both the density and genetic diversity of natural populations of their hosts must be considered in modelling of aquatic systems. In addition, consideration of phage-host interactions is essential in the evaluation of potential risk associated with the environmental release of genetically engineered micro-organisms, as well as in the evaluation of the effectiveness of any released organism in carrying out its desired environmental function.

These studies were supported in part by cooperative agreements nos. CR815234 and CR815282 with the Gulf Breeze Environmental Research Laboratory of the US Environmental Protection Agency and in part by the US Department of Energy, Assistant Secretary for Energy Research, Office of Health and Environmental Research, under contract W-31-109-Eng-38. 


\section{References}

Bergh, Ø., Børsheim, K. Y., Bratbak, G. \& Heldal, M. (1989). High abundance of viruses found in aquatic environments. Nature, London 340, 467-468.

Børsheim, K. Y., Bratbak, G. \& Heldal, M. (1990). Enumeration and biomass estimation of planktonic bacteria and viruses by transmission electron microscopy. Applied and Environmental Microbiology 56, 352-356.

Bratbak, G., Heldal, M., Norland, S. \& Thingstad, T. F. (1990). Viruses as partners in spring bloom microbial trophodynamics. Applied and Environmental Microbiology 56, 1400-1405.

Cadieux, J., Kuzio, J., Milazzo, F. H. \& Kropinski, A. M. (1983). Spontaneous release of lipopolysaccharide by Pseudomonas aeruginosa. Journal of Bacteriology 155, 817-825.

Dawes, E. A. (1985). Starvation, survival, and energy reserves. In Bacteria in Their Natural Environments, pp. 43-80. Edited by $\mathbf{M}$. Fletcher \& G. D. Floodgate. New York: Academic Press.

Ellis, E. L. \& DelbRUCK, M. (1939). The growth of bacteriophage. Journal of General Physiology 22, 365-384.

HAR VEY, R. W. \& YounG, L. Y. (1980). Enumeration of particle-bound and unattached respiring bacteria in the salt marsh environment. Applied and Environmental Microbiology 40, 156-160.

HAYES, W. (1964). The Genetics of Bacteria and their Viruses. New York: John Wiley.

Holloway, B. W., Egan, J. B. \& Monk, M. (1960). Lysogeny in Pseudomonas aeruginosa. Australian Journal of Experimental Biology 38, 321-330.

Iriberri, J., Unanue, M., Barcina, I. \& Egea, L. (1987). Seasonal variation in population density and heterotrophic activity of attached and free-living bacteria in coastal waters. Applied and Environmental Microbiology 53, 2308-2314.

KoKJoHN, T. A. \& MilleR, R. V. (1988). Characterization of the Pseudomonas aeruginosa recA gene: the Les ${ }^{-}$phenotype. Journal of Bacteriology 170, 578-582.

KRISHNAPILLAI, V. (1971). A novel transducing phage. Its role in recognition of a possible new host controlled modification system in Pseudomonas aeruginosa. Molecular and General Genetics 114, 134143.
MCBETH, D. L. (1989). Effect of degradative plasmid CAM-OCT on responses of Pseudomonas aeruginosa bacteria to UV light. Journal of Bacteriology 171, 975-982.

Morgan, A. F. (1979). Transduction of Pseudomonas aeruginosa with a mutant of bacteriophage E79. Journal of Bacteriology 139, 137-140.

MORITA, R. Y. (1985). Starvation and miniaturization of heterotrophs, with special emphasis on maintenance of the starved viable state. In Bacteria in Their Natural Environment, pp. 111-130. Edited by M. Fletcher \& G. D. Floodgate. New York: Academic Press.

Ogunseitan, O. A., Sayler, G. S. \& Miller, R. V. (1990). Dynamic interaction of Pseudomonas aeruginosa and bacteriophages in lake water. Microbial Ecology 19, 171-185.

O'Morchoe, S. B., Ogunseitan, O., Sayler, G. S. \& Miller, R. V. (1988). Conjugal transfer of R68.45 and FP5 between Pseudomonas aeruginosa in a freshwater environment. Applied and Environmental Microbiology 54, 1923-1929.

Proctor, L. M. \& FuHrman, J. A. (1990). Viral mortality of marine bacteria and cyanobacteria. Nature, London 343, 60-62.

RoMIG, W. R. \& BRoDETSKY, A. M. (1961). Isolation and preliminary characterization of bacteriophages of Bacillus subtilis. Journal of Bacteriology 82, 135-141.

RozAK, D. B. \& ColwELl, R. R. (1987). Survival strategies of bacteria in the natural environment. Microbiological Reviews 51, 365-379.

SAYe, D. J., Ogunseitan, O., Sayler, G. S. \& Miller, R. V. (1987). Potential for transduction of plasmids in a natural freshwater environment: effect of plasmid donor concentration and a natural microbial community on transduction in Pseudomonas aeruginosa. Applied and Environmental Microbiology 53, 987-995.

Saye, D. J., Ogunseitan, O. A., Sayler, G. S. \& Miller, R. V. (1990). Transduction of linked chromosomal genes between Pseudomonas aeruginosa during incubation in situ in a freshwater habitat. Applied and Environmental Microbiology 56, 140-145.

TORrella, F. \& Morita, R. Y. (1979). Evidence by electron micrographs for a high incidence of bacteriophage particles in the waters of Yaquina Bay, Oregon: ecological and taxonomical interpretations. Applied and Environmental Microbiology 37, 774-778.

Wiggins, B. A. \& ALEXANDER, M. (1985). Minimum bacterial density for bacteriophage replication: implications for significance of bacteriophages in natural ecosystems. Applied and Environmental Microbiology 49, 19-23. 